UDC 378.011.3-051:81'243

DOI: $10.31470 / 2415-3729-2019-9-87-102$

\title{
Content, Components and European Tendences of the Future Foreign Languages Teachers' Professional Training
}

\section{Sabina Kotsur}

Postgraduate student of the Department of Pedagogy

Pereiaslav-Khmelnytskyi Hryhorii Skovoroda State

Pedagogical University,

$\triangle$ 30, Sukhomlynskyi Str., Pereiaslav-Khmelnytskyi, Kyiv

Region, Ukraine, 08401

E-mail: Sabinyanohka@gvail.com

ORCID: 0000-0003-1112-2946

Date of receipt of the article: December 06, 2018 Article accepted for publication: February 21, 2019

\section{Сутність, складові та свропейські тенденції професійної підготовки майбутніх учителів іноземних мов}

\section{Сабіна Григорівна Коцур}

аспірант кафедри педагогіки

ДВНЗ «Переяслав-Хмельницький державний педагогічний університет імені Григорія Сковороди»,

$\triangle$ вул. Сухомлинського, 30, м. Переяслав-Хмельницький, Київська обл., Україна, 08401

Дата надходження статті: 06 грудня 2018 p. Стаття прийнята до друку: 21 лютого 2019 р.

\section{Abstract}

The article analyzes different approaches to the «professional training of a teacher» definition as a system of organizational-pedagogical measures and vocational training 
systems; a critical study, the improvement and experimental use of ideas; the purposeful, systematic and organized process of pedagogical influences; qualifications in the process of studying in the corresponding direction, specialty, educational program; systems of special knowledge, abilities and skills, competences, qualities. The peculiarities of the professional training of future foreign languages teachers are defined by the author as: a possession of units of a foreign language and the ability to use them in specific situations of communication; a consistency of the initial level of foreign languages knowledge received at school with the goals and objectives, methods and technologies of forming the personality of a student as a future specialist in the process of vocational training; the ratio of theoretical and practical training, special and psycho-pedagogical, methodical preparation; a symmetrical study of two foreign languages and bilingual life (Ukrainian and Russian); knowledge and appreciation of the cultural characteristics of a nation, the language of which is studied.

The author also proposes the definition of the concept of «professional training of future foreign language teachers» as a dynamic system of organizational and pedagogical influences, which is characterized by the unity of goals, content, methods and technologies of professional training of students, which study foreign languages on a multi-lingual basis, and foresees the formation of readiness for their professional activity, a professional competence. The article deals with important components of the future foreign languages teachers' training such as: the theoretical and linguistic training; the practical training; the professional-oriented theoretical training; the methodical one.

The article analyzes the tendencies of future teacher training in the European region. Among the modern European approaches to foreign language teacher training, the author highlights the following main trends: the unification of requirements for professional training in the process of higher education integration into European educational space; the updating of goals and content of studying and teaching foreign languages, changing educational programs and state standards 
taking into account common European trends; the transition from the knowledge concept to the competence paradigm in higher education; the internationalization of education; the use of new flexible technologies in the study of foreign languages, the strengthening of the practical component of vocational training.

Key words: vocational training, future teachers of foreign languages, trends of foreign language education, multilingualism, competences, institutions of higher education.

\section{References}

1. Bezliudna, V. V. (2016). Zmist pidhotovky maibutnikh uchyteliv inozemnykh mov u vyshchykh pedahohichnykh navchalnykh zakladakh. Problemy pidhotovky suchasnoho vchytelia [Content of future foreign languages teachers preparation in higher pedagogical educational institutions] Zb. nauk. prats Umanskoho derzh. ped. un-tu imeni Pavla Tychyny. Uman : FOP Zhovtyi O.O., 13, 80-87 [in Ukrainian].

2. Bezliudna, V. V. (2017). Suchasna systema profesiinoi pidhotovky maibutnikh uchyteliv inozemnykh mov [Modern system of future foreign languages teachers preparation]. Vykladannia mov u vyshchykh navchalnykh zakladakh osvity, 30, 7-16 [in Ukrainian].

3. Bezliudna, V. V. (2016). Profesiina pidhotovka maibutnikh uchyteliv inozemnykh mov u systemi vyshchoi osvity [Professional training of future foreign languages teachers in the system of higher education]. Pedahohichni nauky: teoriia, istoriia, innovatsiini tekhnolohii, 4 (58), 178-185 [in Ukrainian].

4. Bocharnykova, T. F. (2012). Osoblyvosti profesiinopedahohichnoi spriamovanosti maibutnikh uchyteliv inozemnykh mov [Features of vocational and pedagogical orientation of future foreign languages teachers]. Problemy inzhenerno-pedahohichnoi osvity, 36, 21-25 [in Ukrainian].

5. Dubrova, A. S. (2017). Tendentsii profesiinoi pidhotovky vchytelia inozemnoi movy $\mathrm{v}$ konteksti yevropeiskykh vymoh [Trends in the professional training of future foreign languages teachers in the context of European 
requirements]. Naukovi zapysky Rivnenskoho derzh. humanitarnoho un-tu, 17(60), 275-278 [in Ukrainian].

6. Kovalova, S. M. (2005). Suchasni tendentsii pidhotovky maibutnoho vchytelia u krainakh zakhidnoi Yevropy [Contemporary trends in the training of a future teacher in Western European countries]. Visnyk Zhytomyrskoho derzh. un-tu imeni Ivana Franka, 25, 171-173 [in Ukrainian].

7. Pukhovska, L. P. (2000). Suchasni doslidzhennia v haluzi pedahohichnoi osvity u krainakh zakhidnoi Yevropy [Modern research in the field of pedagogical education in the countries of Western Europe]. In Ziaziuna I.A. (Ed.), Neperervna profesiina osvita: problemy, poshuky, perspektyvy: monohrafiia. Kyiv: Vydavnytstvo «Vipol», 565-589 [in Ukrainian].

8. Sidun, M. M. (2013). Formuvannia profesiinoi kompetentnosti maibutnoho vchytelia inozemnoi movy pochatkovoi shkoly zasobamy navchalnykh sytuatsii [Formation of the professional competence of primary school foreign languages teachers by means of educational situations]. Candidate's thesis. Zhytomyr: Zhytomyr Ivan Franko State University [in Ukrainian].

9. Titova, S.V. (2017). Pidhotovka vchyteliv filolohichnykh spetsialnostei do profesiinoi diialnosti $\mathrm{v}$ innovatsiinomu osvitnomu seredovyshchi [Training of teachers of philological specialties for a professional activity in the innovative educational environment]. Candidate's thesis. Pereiaslav-Khmelnytskyi: $\quad$ Pereiaslav-Khmelnytskyi Hryhoriy Skovoroda State Pedagogical University [in Ukrainian].

10. Khomenko, O. V. (2012). Vplyv zahalnoievropeiskykh tendentsii na inshomovnu pidhotovku v Ukraini [European Tendencies Influence on foreign language training in Ukraine]. Pedahohichna osvita: teoriia $i$ praktyka, 11. S. 171-175 [in Ukrainian].

\section{Вступ}

В умовах євроінтеграції та входження України в єдиний європейський освітній простір підвищуються вимоги до 
підготовки майбутніх учителів іноземних мов, які будуть давати учням грунтовні знання та навчати вільному володінню різними мовами. Сьогодні основним завданням сучасних закладів вищої освіти є створення умов для вивчення іноземних мов для міжнародного академічного спілкування в рамках багатомовного освітнього середовищ, перегляд організаційних, технологічних і методичних засад підготовки майбутніх учителів іноземних мов. Досягнути цього можливо шляхом модернізації та реформування освітньої галузі на основі вивчення європейського та міжнародного досвіду навчання студентів в умовах мультилінгвізму.

Сьогодні наша країна прямує курсом євроінтеграції, отже, орієнтується на сучасні європейські документи. Свропейський Союз у XXI столітті надає важливого значення реалізації освітньої стратегії «Свропа 2020», що полягає в оновленні та вдосконаленні системи вищої освіти в країнахчленах ЄС. Сприяння вивченню іноземних мов стало окремим напрямом діяльності Сврокомісії у програмі «Language Learning Policies» («Політика у сфері навчання іноземних мов»), яка актуалізує проблему вдосконалення системи професійної підготовки вчителів іноземних мов.

Однак, у сучасній системі освіти України вивчення іноземних мов пропонуються непропорційно, іншомовна пропозиція обмежується насамперед англійською, німецькою та незначною часткою французької та іспанської мов. Тільки окремі заклади вищої освіти надають можливість вивчати китайську, польську, угорську та інші іноземні мови. Загальноприйняте, що в українських закладах вищої освіти підготовка вчителів іноземних мов здійснюється 3 двох іноземних мов, де англійська вивчається як перша, так i друга. Розповсюдженими є такі поєднання мов для вивчення у вищій школі: англійська (IM1) + німецька (IM2); німецька (IM1) + англійська (IM2); англійська (IM1) + французька (IM2); французька (IM1) + англійська (IM2); «мова країнисусіда» (IM1) + англійська (IM2). Отже, найбільш розповсюдженими в Україні $є$ європейські мови. Їх вивчення передбачає грунтовну професійну підготовку майбутнього вчителя іноземних мов. 
Проблема вдосконалення професійної підготовки вчителів іноземних мов розглядається у ряді досліджень вітчизняних і зарубіжних науковців.

Окремі питання професійної підготовки майбутніх учителів іноземної мови в Україні висвітлюються в працях таких науковців як В. Безлюдна, Т. Бочарникова, В. Гаманюк, О. Місечко, І. Соколова, О. Смутченко, О. Шмирко та ін. Організація професійної підготовки вчителів іноземних мов у різних країнах світу висвітлюється такими українськими вченими як О. Антоненко (Чехія), В. Базуріна (Велика Британія), С. Гринюк (Фінляндія), О. Жижко (Мексика), I. Козубовська, М. Леврінц (Угорщина), С. Процько (Бельгія), I. Сілютіна (Швеція), Л. Черній (США) та ін. Серед сучасних дисертаційних досліджень означеної проблематики виділяються роботи таких науковців як В. Баркасі, О. Биндас, I. Козаченко, С. Тітова, М. Шемуда та ін.

Мета статті - визначити сутність, особливості, складові та європейські тенденції професійної підготовки майбутніх учителів іноземних мов.

\section{Матеріал і методи досліджень}

Обумовлюються теоретичним змістом статті, що передбачає використання саме теоретичних методів дослідження, а саме: аналізу, синтезу, узагальнення сучасної літератури.

\section{Результати та їх обговорення}

У сучасних наукових дослідженнях поняття «професійна підготовка майбутнього вчителя» розглядається авторами з різних позицій. Так, В. Безлюдна цю дефініцію тлумачить як систему організаційно-педагогічних заходів, що зорієнтована на особистісний розвиток студента, метою й кінцевим результатом якої є формування готовності студентів до виконання майбутньої професійної діяльності (Безлюдна, 2016:181-182). Л. Пуховська вважає, що професійна підготовка майбутніх учителів має бути пов'язана 3 критичним вивченням, удосконаленням та експериментальним використанням ідей, що надходять 3 різних джерел, включаючи, з одного боку, знання та вміння досвідчених учителів, зразки педагогічної праці, з іншого - 
різноманітну теоретичну та науково-дослідну літературу, тобто теоретизування про практику (Пуховська, 2000: 580581). М. Сідун тлумачить професійну підготовку вчителя у кількох площинах теоретичного розгляду: як системи навчання, що включає вивчення психології, педагогіки та методики в поєднанні 3 педагогічною практикою (спрямованих на формування особистості вчителя), провідною ланкою якої є педагогічна підготовка; змістовопедагогічних $i$ організаційно-методичних заходів, орієнтованих на забезпечення готовності майбутнього педагога до педагогічної діяльності; певних конкретнопедагогічних компонентів; неперервної освіти, що включає в себе три підсистеми (теоретичну, дослідницьку i практичну) та передбачає поступальність у меті, змісті, методах і формах; єдності загальнопедагогічної (процесу послідовного опанування студентами змісту дисциплін педагогічного циклу) i предметно-методичної підготовки; процесу, що відображає науково й методично обгрунтовані заходи вищих навчальних закладів, спрямовані на формування певного рівня професійної компетентності особистості протягом терміну навчання (Сідун, 2013: 7-8).

Отже, сучасними науковцями професійна підготовка вчителя розглядається як система організачійнопедагогічних заходів або система професійного навчання; критичне вивчення, удосконалення та експериментальне використання ідей; иілеспрямований, планомірний $i$ організований процес педагогічних впливів; кваліфікації в процесі навчання за відповідним напрямом, спеціальністю, освітньої програмою; система спеціальних знань, умінь $i$ навичок, компетениій, якостей тощо. Вчені констатують прямий зв’язок професійної підготовки з готовністю до професійної діяльності та професійною компетентністю.

Погоджуємося 3 висновками С. Тітової, «що результатом професійної підготовки (I. Зимня. Ю. Сенько, B. Сластьонін, Н. Кобзар) є готовність випускника вищої педагогічної школи до педагогічної діяльності, а результатом професійної педагогічної освіти $€$ професійна компетентність. Готовність до професійної діяльності як 
новоутворення майбутнього педагога є фундаментом його професійної компетентності. Тобто, і готовність, i компетентність - це рівні професійної педагогічної майстерності» (Тітова, 2017: 7). Таким чином, і готовність до професійної діяльності й основи професійної компетентності формуються у сучасних закладах вищої освіти, однак, поняття професійної компетентності є значно ширшим i передбачає довготривалий етап становлення у процесі набуття сучасним вчителем практичного досвіду роботи.

Професійна підготовка вчителів різних спеціальностей має свою конкретну специфіку. Серед особливостей професійної підготовки майбутнього учителя іноземної мови можна виділити наступні:

- володіння одиницями іноземної мови й уміння вживати їх у конкретних ситуаціях спілкування;

- узгодженість вихідного рівня знань іноземних мов, отриманих у школі, з цілями і завданнями, методами і технологіями формування особистості студента як майбутнього фахівця у процесі професійної підготовки;

- співвідношення теоретичної та практичної підготовки, спеціальної і психолого-педагогічної, методичної підготовки;

- симетричне вивчення двох іноземних мов та двомовне середовище існування (українська та російська мова);

- знання та цінування культурних особливостей народів, мова яких вивчається.

3 урахуванням цих особливостей подано авторське бачення поняття «професійна підготовка майбутніх учителів іноземних мов» як динамічної системи організаційнопедагогічних впливів, щуо характеризуються єдністю иілеей, змісту, методів та технологій професійного навчання студентів іноземної мови на мультилінгвальній основі та передбачають формування у них готовності до професійної діяльності, професійної компетентності.

Аналіз сучасної психолого-педагогічної літератури доводить, науковці виділяють різні складові професійної підготовки майбутніх учителів іноземних мов. Так, В. Безлюдна відмічає, що професійна підготовка вчителя 
іноземної мови у вищих педагогічних закладах освіти включає: а) мовну теоретичну підготовку (знання теорії та історії іноземної мови); б) мовну практичну підготовку (професійно-педагогічне вдосконалення в межах школи); в) методичну підготовку (знання теорії та володіння навичками та вміннями працювати з мовним і мовним матеріалом при його введенні, закріпленні i активізація, формування методичного мислення) (Безлюдна, 2016: 85). Цей же науковець визначає такі основні складники системи професійної підготовки майбутніх учителів іноземних мов, а саме: навчально-організаційну роботу, використання інноваційних технологій, організацію педагогічної практики, організацію самостійнӧ̈ та індивідуальної роботи студентів, дистанційну освіту, контроль успішності студентів (Безлюдна, 2017: 9). Автор робить висновок, що сучасна система професійної підготовки майбутніх учителів іноземних мов характеризується уніфікацією i стандартизацією навчальних планів і програм, збільшенням кількості годин для самостійної роботи, використанням різноманітних інноваційних, інтерактивних, мультимедійних технологій, що створює максимально сприятливі умови для професійного розвитку студентів, забезпечуючи підготовку, що відповідає зростаючим вимогам до сучасного вчителя, його професійно-особистісних якостей (Безлюдна, 2017: 14).

У нашому дослідженні спираємося на різновиди професійної підготовки майбутніх учителів іноземних мов, на які вказує Т. Бочарникова. Автор вважає, що професійна підготовка вчителя іноземної мови складається з теоретиколінгвістичної підготовки; практичнӧ̈ підготовки; професійно-орієнтованої теоретичної підготовки; методичної підготовки. Науковець зазначає, що теоретиколінгвістична підготовка вчителя іноземної мови передбачає забезпечення знанням теорії та історії іноземної мови, яка вивчається; розвиток інтелектуального потенціалу студентів, навичок аналітичного мислення; вміння працювати 3 науковою літературою, визначати суть та характер невирішених наукових проблем, пропонувати свої варіанти вирішення; вміння узагальнювати і класифікувати 
емпіричний матеріал. Практична підготовка передбачає професійно-трудову діяльність (проведення уроків іноземної мови у школі та позакласної роботи з іноземної мови; професійно-педагогічне удосконалення шляхом самоосвіти i на спеціальних курсах підвищення кваліфікації) та соціально-культурну (діяльність вчителя за межами школи: спілкування з носіями мови, робота перекладачем та ін.). Професійно орієнтована теоретична підготовка забезпечення знань теорії педагогіки; теоретичних основ організації навчально-виховного процесу в різних типах середніх навчальних закладів, зокрема і з іноземної мови; формування вмінь проведення самостійного педагогічного дослідження. Методична підготовка сприяє забезпеченню знань $з$ теорії і методики навчання іноземних мов; навчання методичних основ організації навчально-виховного процесу з іноземних мов у різних типах середніх навчальних закладів; формування вмінь самостійного методичного дослідження (Бочарникова, 2012: 21-22).

Усі різновиди професійної підготовки майбутніх учителів іноземних мов в Україні здійснюються у відповідності до стандартів вищої освіти. 3 прийняттям Закону України «Про вищу освіту» заклади вищої освіти отримали академічну автономію, що надає їм можливість розробляти свої освітньо-професійні та освітньо-наукові програми на компетентнісній основіз урахуванням переліку необхідних компетентностей майбутніх фахівців (загальних, професійних). Серед професійних компетенцій передбачається розвиток комунікативних (іншомовних) компетенцій, що засвідчують високий рівень володіння іноземною мовою та охоплюють групи мовленнєвих (вміння адекватно й доречно, практично користуватися мовою в конкретних ситуаціях), лінгвістичних (знання про системи та структури мов, що вивчаються, правила їх функціонування у процесі комунікації), соціокультурних (здатність користуватися елементами соціокультурного контексту, релевантними для породження і сприйняття мовлення з точки зору носіїв мови), сочіолінгвістичних (здатність відбирати лінгвістичні засоби відповідно до соціальних умов 
спілкування), компенсаторних (здатність заповнити прогалини у мовній, мовленнєвій та соціокультурній складовій), країнознавчих (вміння проводити краєзнавчу науково-дослідну роботу), навчальних (спроможність самостійно працювати і навчатися), стратегічних (використання різних стратегій в умовах взаємодії з людьми i навколишнім світом), дискурсивних (вміння планувати мовну поведінку відповідно до функціональної мети спілкування) та інших компетенцій як здатностей майбутніх учителів ефективно здійснювати процес комунікації у міжособистісній взаємодії, ефективно формулювати власні думки, ідеї у різноманітних ситуаціях. Програмні результати навчання визначаються у певних знаннях, уміннях, навичках комунікації.

В. Безлюдна доводить, що сучасна освіта в галузі іноземних мов орієнтована не лише на здобуття студентами лексичних та граматичних знань, а й розвиток тих професійних умінь, які будуть необхідними в майбутній професійній діяльності студентів. Основу цієї діяльності, на думку автора, складають вісім видів умінь:

- проектувальні (уміння спланувати будь-який вид роботи);

- адаптаційні (уміння застосувати свій план у конкретних навчальних умовах);

- організаційні (уміння організувати будь-який вид роботи);

- мотиваціийні (уміння мотивувати учнів до навчальної діяльності);

- комунікативні (уміння спілкуватися на уроці і поза ним);

- уміння контролю й самоконтролю;

- nізнавальні (уміння вести дослідницьку діяльність)

- допоміжні (уміння співати, грати на інструменті, малювати тощо).

Саме ці вміння, на думку вченої, в сукупності і складають основу, стрижень професійної діяльності (Безлюдна, 2016: 181). Отже, професійна підготовка майбутніх учителів іноземних мов у закладах вищої освіти 
регулюється освітньо-професійними і освітньо-науковими програмами, сформованими згідно стандартів вищої освіти на компетентнісній основі. Основними вміннями, якими потрібно оволодіти студентам у процесі професійної підготовки є проектувальні, адаптаційні, організаційні, мотиваційні, комунікативні, уміння контролю й самоконтролю, пізнавальні.

Тепер зупинимося на визначенні тенденцій професійної підготовки майбутніх вчителів у європейському регіоні як важливого моменту системного аналізу та глобального моделювання системи освіти. Знання цих тенденцій відкриває нові шляхи для прогнозування i реального відродження освіти, подолання емпіризму в педагогічній науці i практиці, вдосконалення освітнього процесу. С. Ковальова виокремлює наступні тендениії підготовки майбутнього вчителя:

- перехід до вищої багаторівневої педагогічної освіти;

- посилення інноваційності у сфері підготовки вчителів, яка передбачає створення для студентів можливостей займати активну позицію у навчальному процесі, освоювати новий досвід на основі цілеспрямованого формування творчого і критичного мислення, набуття власного досвіду;

- професіоналізація відбору осіб для отримання педагогічної освіти, уточнення критеріїв та підвищенню вимог до її здобувачів як на етапі вступу до вишу, так і в процесі навчання у ньому;

- використання нових гнучких технологій, пошукової орієнтації в освіті і професійній підготовці вчителів, яка передбачає цілісне включення студентів-майбутніх педагогів до системи професійно-значущих відносин, прилучення їх до вирішення педагогічних завдань, забезпечення системотворчих функцій педагогічної практики в іii єдності 3 теоретичною професійною підготовкою (Ковальова, 2005: 171-173).

А. Дуброва окреслює наступні тендениії професійної підготовки вчителя іноземної мови в контексті європейських вимог: інтеграція в європейський освітянський простір; 
оновлення цілей і змісту навчання та вивчення іноземних мов у середніх і вищих закладах освіти; особистісна і професійна орієнтація системи освіти; пріоритет загальнолюдських і національних цінностей; забезпечення якості освіти на основі новітніх досягнень науки і соціальної практики; володіння комунікативними (іншомовними) компетенціями (Дуброва, 2017: 275-278).

О. Хоменко визначає і аналізує основні тенденції вирішення проблем іншомовної підготовки та робить висновок про їх глобальний характер, незважаючи на полікультурність, різноманітність світу, у якому живемо, різні освітні системи тощо. До основних загальноєвропейських тенденцій, що впливають на іншомовну підготовку в Україні автор відносить:

- тенденцію до зміни освітніх програм та державних стандартів 3 урахуванням загальноєвропейських трендів;

- неперервність освіти, освіта протягом життя;

- тенденцію повороту від концепції «знання» до концепції «компетентність»;

- інтернаціоналізацію освіти (Хоменко, 2012: 171-175).

\section{Висновки}

Отже, європейська спільнота опікується рівнем іншомовної грамотності українського населення, сприяє утвердженню європейських вимог підготовки майбутніх учителів іноземних мов та студентів інших спеціальностей та учнів. Серед сучасних європейських підходів до іншомовної підготовки вчителів можна виділити такі основні тенденції: уніфікація вимог до професійної підготовки у процесі інтеграції вищої школи в європейський освітянський простір; оновлення цілей і змісту навчання та вивчення іноземних мов, зміни освітніх програм та державних стандартів з урахуванням загальноєвропейських трендів; перехід у вищій школі від знаннєвої концепції до компетентнісної парадигми; інтернаціоналізація освіти; використання нових гнучких технологій у процесі вивчення іноземних мов, посилення практичної складової професійної підготовки. 


\section{Література}

1. Безлюдна В. В. Зміст підготовки майбутніх учителів іноземних мов у вищих педагогічних навчальних закладах. Проблеми підготовки сучасного вчителя : зб. наук. праць Уманського держ. пед. ун-ту імені Павла Тичини / [ред. кол. : Безлюдний О. І. (гол. ред.) та ін.]. Умань : ФОП Жовтий О. О. 2016. Вип. 13. С. 80-87.

2. Безлюдна В. В. Сучасна система професійної підготовки майбутніх учителів іноземних мов. Викладання мов у вищих навчальних закладах освіти. 2017. Вип. 30. С. 7-16.

3. Безлюдна В. Професійна підготовка майбутніх учителів іноземних мов у системі вищої освіти. Педагогічні науки: теорія, історія, інноваційні технологї. 2016. № 4 (58). C. 178-185.

4. Бочарникова Т. Ф., Особливості професійнопедагогічної спрямованості майбутніх учителів іноземних мов. Проблеми інженерно-педагогічної освіти. 2012. № 36. С. 21-25.

5. Дуброва А. С. Тенденції професійної підготовки вчителя іноземної мови в контексті європейських вимог. Наукові записки Рівненського держ. гуманітарного ун-ту. 2017. Вип. 17(60). С. 275-278.

6. Ковальова С. М. Сучасні тенденції підготовки майбутнього вчителя у країнах західної Свропи. Вісник Житомирського держ. ун-ту імені Івана Франка. 2005. № 25. C. 171-173.

7. Пуховська Л. П. Сучасні дослідження в галузі педагогічної освіти у країнах західної Свропи. Неперервна професійна освіта: проблеми, пошуки, перспективи: монографія / За ред. І.А. Зязюна. Київ: Видавництво «Віпол», 2000. С. 565-589.

8. Сідун М. М. Формування професійної компетентності майбутнього вчителя іноземної мови початкової школи засобами навчальних ситуацій: автореф. дис. ...канд. пед. наук: 13.00.04 / Житомирський держ. ун-т імені Івана Франка. Житомир, 2013. 22 с. 
9. Тітова С. В. Підготовка вчителів філологічних спеціальностей до професійної діяльності в інноваційному освітньому середовищі: автореф. дис. ... канд. пед. наук: 13.00.04 / ДВНЗ ПереяславХмельницький держ. пед. ун-т імені Григорія Сковороди. Переяслав-Хмельницький, 2017. 22 с.

10. Хоменко О. В. Вплив загальноєвропейських тенденцій на іншомовну підготовку в Україні. Педагогічна освіта: теорія і практика, 2012. Вип. 11. С. 171-175.

\section{Коцур С.Г.}

\section{Сутність, складові та свропейські тенденції професійної підготовки майбутніх учителів іноземних мов}

\section{Анотація}

У статті аналізуються різні підходи до визначення поняття «професійна підготовка вчителя». Автор визначає особливості професійної підготовки майбутніх учителів іноземних мов, пропонує авторське визначення цього поняття як динамічної системи організаційно-педагогічних впливів, що характеризуються єдністю цілей, змісту, методів та технологій професійного навчання студентів іноземної мови на мультилінгвальній основі та передбачають формування у них готовності до професійної діяльності, професійної компетентності. У статті розглядаються такі складові професійної підготовки майбутніх учителів іноземних мов: теоретико-лінгвістична; практична; професійно-орієнтована теоретична; методична. На основі аналізу сучасних європейських підходів до іншомовної підготовки вчителів автор виділяє основні тенденції їх професійної підготовки.

Ключові слова: професійна підготовка, майбутні вчителі іноземних мов, тенденції іншомовної освіти, мультилінгвізм, компетенції, заклади вищої освіти. 


\section{Коцур С.Г.}

\section{Сущность, составляющие и европейские тенденции профессиональной подготовке будущих учителей иностранных языков}

Аннотация
В статье анализируются различные подходы к определению понятия «профессиональная подготовка учителя». Автор определяет особенности профессиональной подготовки будущих учителей иностранных языков, предлагает авторское определение этого понятия как динамической системы организационно-педагогических воздействий, характеризующихся единством целей, содержания, методов и технологий профессионального обучения студентов иностранному языку на мультилингвальной основе и предусматривают формирование у них готовности к профессиональной деятельности, профессиональной компетентности. В статье рассматриваются такие составляющие профессиональной подготовки будущих учителей иностранных языков: теоретико-лингвистическая;

профессионально-ориентированная практическая; теоретическая; методическая. На основе анализа современных европейских подходов к иноязычной подготовки учителей автор выделяет основные тенденции их профессиональной подготовки.

Ключевые слова: профессиональная подготовка, будущие учителя иностранных языков, тенденции иноязычного образования, мультилингвизм, компетенции, высшие учебные заведения. 